\title{
HAJDÚBÖSZÖRMÉNY TELEPÜLÉSMORFOLÓGIAI KÉPZŐDMÉNYEINEK VÁLTOZÁSAI A XIX-XX. SZÁZADBAN
}

\author{
(Morphological changes in the 19-20th centuries in Hajdúböszörmény)
}

\section{TÓTH ANTAL}

Jelen tanulmány azokat a településmorfológiai képződményeket (alaprajz, utcahálózat, telekrend, beépítési mód) vizsgálja, amelyek között a város élete folyik. Hiánypótlásra törekszik, hiszen az urbanizáció morfológiai vonatkozásai még napjainkban sincsenek kellően feltárva (Csapó 1990). Dolgozatomban elsősorban a település alaprajzának és arculatának fejlỏdéstörténetét elemeztem.

Választásomat Hajdúböszörmény településfôldrajzi sajátosságai indokolják. A város megjelenésében ma is hordozza történetiségét; legértékesebb múemléke maga a város, illetve annak településszerkezete.

A településstruktúrák egyik jellemzője a szerkezet (városalaprajz, utcahálózat rendszere). Egy település alaprajzának kialakulása hosszú és bonyolult folyamat eredménye, a természeti és társadalmi adottságok függvénye. Dinamikus struktúra ez, amely állandó változásban van.

Hajdúböszörmény alaprajzát a maga falúkorabeli állapotából örökölte. A város az ún. kétbeltelkes vagy ólaskertes települések legklasszikusabb példája. Nem tudjuk mikor alakult ki ez a településforma (egyes kutatások - pl.: Györffy - a honfoglalás korabeli magyar társadalom téli szállásrendjéböl eredeztetik), a hajdúk már örökölték ezt a településszerkezetet.

A sík térszínen fejlödő települések a kerek formára törekszenek. A városközpontnak mindig vonzó ereje van, így ha nincs más tényező, ami ezt akadályozná, a város a központtól kifelé gyürüsen növekszik. A központ a várostest geometriai központjában fekszik, és azt a perem felöl a központ felé haladva különböző övezetek veszik körül.

A település legbelső magja a várakhoz hasonló jellegzetes erödítmény (templomerőd) volt. A templomot fal- vagy kókerítés vette körül (maradványa ma is látható a református templom mellett, a Bocskai téren). A belsóségben a lakóházak rendszertelenül épültek, közel álltak egymáshoz, kezdetben telek vagy kerítés, igazi utcák nélkủl. Árokrendszer, palánk (hajdúpalánk) vette körül ezt az elliptikus, majdnem kör alakú belső magot, amelyen 4 kapu biztosította az átjárást. Az Árokalj átmenetet képzett a belváros és a kertségi övezet között. A kertségi övezet gazdasági (ólaskertek) és védelmi funkciót látott el. Tölcsérszerűen kiszélesedő sugaras utcák, és ugyancsak körkörös forma jellemezte. Minden beltelekhez tartozott egy-egy kert, innen kapta nevét ("kétbeltelkes") ez a település alaprajzi típusa (Gyórffy) (1. ábra). A kettőstelek-birtoklás a hajdúk félkatonai jellegű településrendszerének legékesebb bizonyítéka. Ez a településstruktúra a hajdúvárosok mindegyikére jellemző volt, de legtisztábban Hajdủböszörmény képviselte a rendszer jellegzetességeit (Kathy 1979.). 


\section{1. ÁBRA}

Hajdúböszörmény alaprajza 1782-ben (Györffy István után)

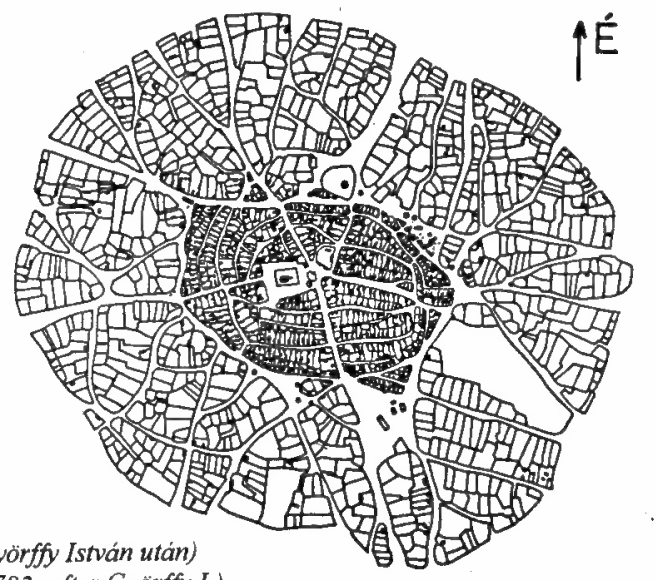

(The sematic map of Hajdüböszörmény in 1782, after Györffy I.)

\section{2. ÁBRA}

Hajdúböszörmény alaprajza 1842-ben (Györffy István után)

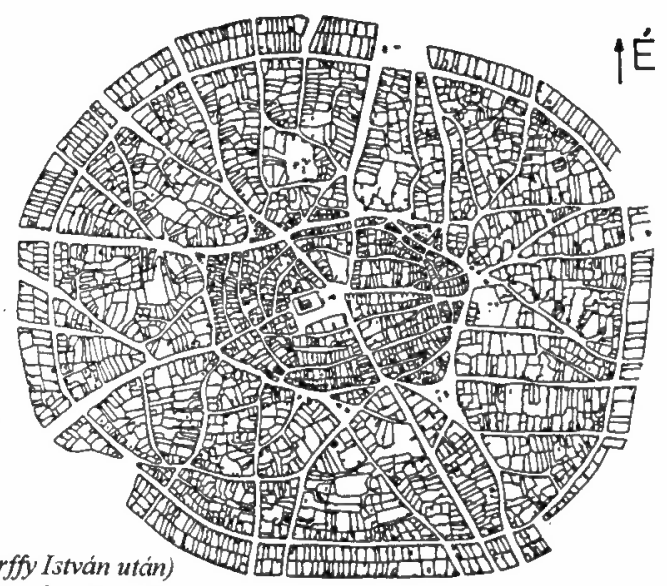

(The sematic map of Hajduböszörmény in 1842, after Györffy I.)

3. ÁBRA

Hajdibös:örmény alapraj=a 1926-ben (Györffy István utän) (The sematic map of Hajdibös=örmény in 1926, after Gyorffy

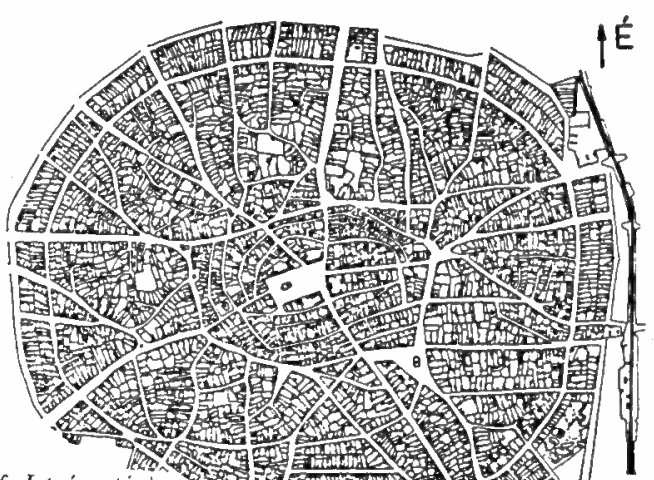

怕 
Bár a kutatás ezúttal nem terjedt ki a település külterületére, azt feltétlenül meg kell jegyezni, hogy a várost három részre osztott határ ơvezte. A belső legelöt a szántóterület követte, azon kívül pedig a nagy kiterjedésủ legelök, vagy puszták öve (kủlsỏ legeló) húzódott.

A városmagot 5 sugárszerủ út (Debrecen-Nánás, Hadház-Újváros, Dorogi út) keresztezte. Ez a tradicionális törzsúthálózat $\mathrm{ma}$ is alapvetỏen meghatározó eleme Hajdúböszörmény alaprajzának. A város térbeli középpontja körül fokozatosan íves vonalvezetésủ utcák, egymással többé-kevésbé párhuzamosan haladó körutak alakultak ki, amelyek a város térbeli növekedésének bizonyítékai. A belső városmagot egyre inkább sủrủ beépítettség, apró telkek, szúk utcák kezdték el jellemezni.

A XVIII. sz. második felétól a telkek aprózódása, a beépítetlen területsáv beépítése elörehaladt. A városi lakosság lélekszámának növekedése (1718: kb. 1700 fö; 1780: 5610 fơ; 1828: 14660 fỏ a természetes szaporodás, de még inkább a nagyarányú beköltözés révén) (Szendrey 1973.), az intenzív földhasznosítás, a tovább már nem osztható belsó háztelkek vezettek a nagy kiterjedésú kertek és az Árokalja területének benépesủléséhez, amely a XVIII. sz. végétől (1797) már szabályozott formában zajlott. A XIX. sz. első felében a kertövezet teljesen beépủlt lakóházakkal (1782-ben még csak a kertek 1/4-én volt lakóház, 1842-ben szinte 100\%-án) (1, 2. ábra). 1810-ben a régi belsőségen 633 ház állt, míg az árokalji részen 324, a kertségi területen pedig már 1098 (Rä́cz 1973). A régi kertségek beépülésével felbomlott a kétbeltelkes elrendezỏdés, a beltelkek és a kert függetlenedett egymástól, a XIX. sz. második felében a város szerves részévé vált az egykori ólaskert és az Árokalja területe. Az 1926-os alaprajzot (3. ábra) tanulmányozva megállapítható, hogy az egykori mag és a kertségi öv beépítettségének mértékében és a teleknagyságban a kủlönbségek már jóval kisebbekké váltak.

Az óriási kerteket sokan felparcellázták, de az úthálózat és a kertségi tömbök körvonala megmaradt. A nagyméretú kertek építészeti feltárását zsákutcákkal, zugokkal oldották meg, amelyek a településszerkezet egyik jellegzetességét adják. A zugok, zsákutcák elágazásával az ỏsi telektömbök belsejében valóságos labirintusok alakultak ki (3. ábra).

Hajdúböszörmény alaprajzának sajátossága, a szabályos (körutak, sugárutak) és a szabálytalan (zegzugos utcahálózat) jelleg.

A város alaprajzának alakulását a későbbi évtizedekben nagyban befolyásolta a különböző szőlöskertek létrehozása. A szőlőskerteket a város belső legelőjének területéből alakították ki gazdasági okok (kerti kultúra elterjedése) miatt és a sivár, homokos terület müvelésbe vétele céljából. 1715-ben a Vénkert, 1791-ben a Nadrágoskert, 1794-ben a Zaboskert, 1797-ben a Középkert nevü szölöskerteket hozták létre. Az 1840-es évektől kezdődött el a külső szólóskertek kialakítása.

A kedvezó talajadottságok és a város belterületeinek állandó és nagyarányú népességnövekedése (1890: 21238, 1910: 28159 fö) (Szendrey 1973) miatt engedélyezték 1895-tôl a Középkertben a lakóházépítést. Hivatalosan is megindulhatott a telekosztás, a régi szőlöskertek egy része fokozatosan benépesült, s a Középkert, Vénkert területe már az 1930-as népszámlálásnál sem számított külterủletnek (4. ábra).

Ugyancsak a XX. század elsó évtizedeiben kezdtek kialakulni az ún. Kisböszörményben a napszámosok, nincstelen agrárproletárok szegényes otthonai, amelyek késóbb ugyancsak belterület részévé váltak (4. ábra). 


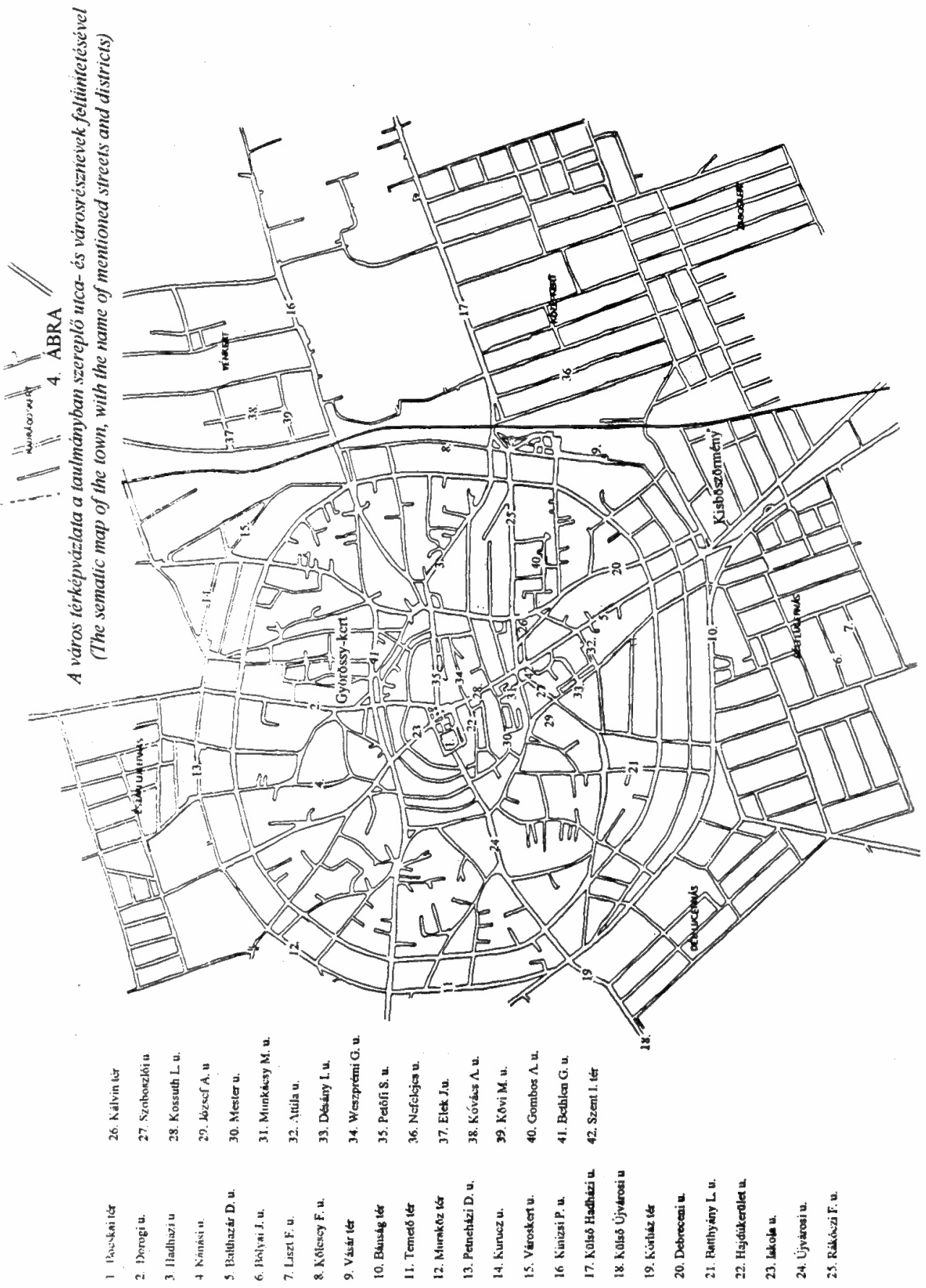


Az 1930-as években a város északi és déli részein az ún. Északi- és Déli-Lucernás területén volt telekosztás (4. ábra). Ezek csak 1945 után épültek be. A rendezett utcavonalak az egyenes, derékszögben kereszteződő utcák már a tervszerüség bizonyítékai. A cigánytelep felszámolása után a cigánycsaládokat a Déli-Lucernás újonnan kialakított utcáiban (Bolyai J. u., Liszt F. u.) telepítették le (4. ábra).

A külsó körúton tứl is új lakótőmbők jöttek létre, és az egykori hajdútelepủlés legkulső vonalát is túllépve újabb körút van kialakulóban (Kölcsey F. u. - Vásár tér - Bánság tér Temető tér - Murakőz tér - Petneházi D. u. - Kurucz u. - Városkert u.) (4. ábra).

A XX. sz. későbbi évtizedeiben nemcsak az egykori belső mag, Árokalja, kertség terủletén törekedtek a zártabb, a területet jobban kihasználó építkezésekkel nagyobb fokú horizontális zártság megvalósítására, hanem az egykori szölöskertek benépesülése, beépülése is egyre nagyobb méreteket öltött. Például a Vénkertben 1959-1996. között 147\%-kal, 37l-röl 544-re nőtt meg a lakások száma, ami a beépítettség növekedésének egyik bizonyítéka.

A településhálózat struktúrája a fejlődés ellenére elavult volt, Hajdúböszörmény még az 1950-es évek elején is falusias benyomást keltett. Ezért 1957-től megkezdték a város hosszú távú rendezési tervének elkészítését. A három-, majd otéves tervek keretében állami ês szövetkezeti többszintes bérlakások építését határozták el. Sajnos egyes építkezések az utcahálózatok törésvonalait, a településszerkezetet nagyon megbontották, pótolhatatlan károkat okoztak a város építészeti emlékeiben.

A település alaprajzában nagy változásokat okozott az '50-es, '60-as évek ipartelepítése is. $\mathrm{Az}$ '50-es években indult meg az első iparvállalatok megalakítása, letelepítése Hajdúböszörményben (Textilipari Vállalat, Tejüzem, Faipari Vállalat, Gépjavító Állomás, Müszaki KTSZ), amelyet a '60-as évek második felében újabb üzemek, gyáregységek létrehozása, a városba vonzása követett (Szalag- és Zsinórgyár, Rico Kötszermüvek, Egyesült Izzólámpa és Villamossági Rt. alkatrészgyára, Lörinci Vattagyár gyáregysége). Az ipari övezetet ott alakították ki, ahol rendelkezésre állt nagyobb szabad terület, és a talajadottságok is megfelelőek voltak. A nagy helyigényü üzemek, gyáregységek, így az egykori szőlőskertek és a régi belsőségi perem közötti egykori belső legelö területén épültek fel. A keleti ipari övezet a Vénkert és Középkert közötti szabad területen a Keleti köztemetötől É-ra a Kinizsi P. utca, illetve K-re a Külső Hadházi út mentén jött létre (4. ábra). A nyugati iparövezet (a Köztemetőtől D-re, DK-re - Kórház tér, Külső Újvárosi u.) kialakítása inkább csak papíron valósult meg, a valóságban itt csak néhány telephely (pl.: Mezógép) alakult ki (4. ábra).

$\mathrm{Az}$ elmúlt évtizedek során tehát a földrajzi értelemben vett város térbelileg jelentősen kitágult. A belterület nagyarányú népességnövekedése magával hozta újabb területek beépítését és új házhelyek osztását, aminek következményeként a belső lakóöv jelentösen kiterjedt, és kialakult egy külső lakóöv is (Csapó 1990). Az Alfóld iparosítási programjának keretében végrehajtott ipartelepítés pedig egy jelentékeny iparövet hozott létre Hajdúböszörmény keleti részén, amely szintén hozzájárult a város belterületének növekedéséhez.

Bár a településszerkezet az elmúlt évszázadok során jelentős mértékben átalakult, ma is örzi a kétbeltelküség emlékét, ugyanis a település övezetekre tagolódik. 
Ezek az övezetek a következốk:

1. Belsō mag

Viszonylag sürü beépítésü, és nagyjából elliptikus formájú (az elliptikus forma nagytengelye K-Ny-i, kistengelye É-D-i irányú). Utcái a belső mag kontúrját követik, vagyis közel körkörös alakúak. A gyürüsen növekvő elliptikus alakzatok a város területi növekedését mutatják. Az É-D-i, illetve a K-Ny-i irányba kirajzolódó utcák megközelítőleg azonos területekre osztva metszik át, de még van egy É-i sugárirányú átvezetés is.

A késöbbi telekmegosztások ellenére is mindmáig érzékelhető az eredetileg szabályosan kialakított telekrendszer, vagyis megközelítőleg szabályos alakúak az általában kisméretü telkek.

2. Árokalja

$\mathrm{Az}$ óriás telkek felparcellázása érdekes utcahálózatot, a nagyméretü tömbök felszámolására szolgáló zsákutcák, zugok rendszerét alakította ki. A nagy kertek feldarabolódása után a telkek általában szabálytalan alakúakká váltak. A telekméretek kisebbek, nagyfokú szóródást mutatnak.

3. Kertség

A régi külső árok helyén egy átlagosan $2 \mathrm{~km}$ átméröjü körút keletkezett. Számos sugárút szeli át, de ezeknek nagyobb része nem kapcsolódik a belváros hasonló útjaihoz, az utak csak az egykori ólaskert öv belső peremén kezdődnek (pl.: Debreceni u., Batthyány L. u.). A szabálytalan alakú telkek mai állapotukban is szépen mutatják a rendezést sok helyen nélkülöző, zugokkal kuszált korábbi településképet. A telekméretek általában nagyobbak, és többé-kevésbé táblaszerủek.

4. Újosztás

Hasonlóan a belsö mag területéhez, az egyes telkek itt is koncentrikusan elhelyezkedő utak között, szabályos elrendeződésben sorakoznak. A körútra történö kijárás ugyanis lehetővé tette a szétdarabolódó kertek szabályos felparcellázását (Novák 1975).

5. Egykori szölöskertek (Vénkert, Középkert, Zaboskert), Kisböszörmény, Északi-és Déli Lucernás

Az utcavonalak rendezettek, jellemzőek az egyenes, derékszögben kereszteződő utcák. A telkek általában nagyobbak, bár a méretek szóródása itt is jellemző. Az elmúlt évtizedek beépülése ellenére még napjainkban is ezek a területek a legkevésbé beépítettek.

A tanulmány második részében összehasonlitó morfológiai vizsgálat eredményeit dolgoztam fel. A korábbi morfológiai kép elemzését, az összehasonlítás lehetőségét Mendöl Tibor hatvan évvel ezelött készült településföldrajzi kutatásai tették lehetővé. Elsősorban a városmag alakjának, helyének, szerkezetének és nagyságának változását vizsgáltam a morfológiai formaelemek, beépitési módok feltárásával, azok térbeli elrendezödésének térképre vitelével.

Mendöl Tibor módszerét alkalmazva bizonyos körzeten belül minden utcát bejártam, s a térképen minden egyes lakóházat, intézmény épületét elöre meghatározott kulcs szerint számmal, illetve betưvel jelöltem. Külön jelet alkalmaztam az üzletek jelölésére. Az összehasonlíthatóság érdekében az 1936-ban használt formaelemeket használtam a mai állapot leírásánál; kiegészítve a II. világháború után új típusként megjelenỏ családi házakkal, a '80-as évek modern, azonos terv alapján épített, földszintes, tetőtér-beépitéses, 
vagy egyemeletes társasházaival és a '60-as évek elejétől Hajdúböszörményben új elemként megjelenő többszintes sorházakkal, lakótömbökkel.

Amíg a város alapvető szerkezeti rendjében az elmúlt két évszázad során lényeges változás nem történt, addig megjelenésében, arculatában kétszer, háromszor is átformálódott.

Hajdúböszörményben a XIX. sz. közepétől indult el a fejlödés a város térbeli megjelenésében. A belső részeken a falusias, fésüs beépítés helyett városias, helyenként teljesen zártsorú építkezés kezdődőtt. A XIX. század második felétöl tudatos városrendezés keretében alakítják ki a fötér, a Bocskai tér képét. A régi, fơldszintes közés magánépületeket lebontották, városias jellegü, közcélú épületeket épitettek a helyükre. A gimnázium, a városháza, az elemi iskola felépítésével, a régi református templom átalakításával, a kerületház kibővítésével az ország egyik legszebb tere alakult ki.

A XIX. sz. végére a legrégibb 4 utca zártsorú beépítést kapott, a megemelt földszintes, eklektikus házak párkánymagassága elérte az átlagos, egyemeletes házakét. A vertikális tagoltság alacsony szintü volt. Az emeletes házak nem alkottak összefüggő sort, legfeljebb szétszórtan bár, de egymás közelében helyezkedtek el (1935-ben a belső mag épületeinek csak kb. 6\%-a volt emeletes). A városmag igen élesen kirajzolódó, a településnek szinte a geometriai kỏzéppontjában alakult ki. Hatalmas, szépen parkozott a fótér, melyet az igen nagy, égyemeletes középületek csaknem körülzártak. Az erősen hézagos üzletnegyed, mint egy ötágú csillag, az innen sugarasan szétágazó foútvonalak elejét foglalta el - nagyjából az ólaskertek övéig. A foútvonalak által határolt körcikkek belsejében azonban nagy volt a morfológiai zűrzavar, a falusias formacsoport reliktumai a fötér szomszédságában is felbukkantak (pl.: a mai Hajdúkerület u., Iskola u., Újvárosi u.) (Mendöl 1936). Hajdúböszörmény a magjában kisvárosias, óriásfaluszerü település volt - a kicsi városmagból például még a XIX. sz. végén is egészen falusias jellegũ utcán lehetett csak kijutni a vasútállomáshoz. Az 1885-ben átadott vasútvonal (Debrecen-Hajdúnánás között) a későbbiekben természetesen pozitív változásokat eredményezett a morfológiai képben, hiszen a kedvezỏ forgalmi fekvés a Rákóczi utca, Kálvin tér környékére vonzotta a lakosság módosabb kispolgári rétegét.

Hajdúböszörményben ekkor morfológiai szempontból 3 domináns övezetet lehetett elkülöníteni:

Városközpont

Kisvárosi formacsoport, azaz a kisvárosi zárt lakónegyed és az erősen hézagos kisvárosi üzletnegyed jellemezték. A kisvárosi zárt lakónegyedben a házak hossztengelye párhuzamos volt az utcával. Attól függően, hogy összeépültek, vagy elkülönülten álltak, különböztethetóek meg a zártsorú és a félig zárt kispolgári sorházak. Udvar, kert csak a telektömbök belsejében volt. A kisvárosi üzletnegyedre a szakboltok, az áruház és a piac jelenléte volt jellemzö. A városközpontban voltak megtalálhatók a legjelentősebb középületek is. Itt is kevés volt a többszintes épület (egyemeletesnél magasabb nem is volt). A négy domináns övezet közuil ennek volt a legkisebb a területe.

Félagrár öv

Ahogyan a neve is mutatja, kevert forma, azaz hézagos kispolgári sorházak, és elsősorban - falusias típusú épületek jellemezték.

Falusias öv

Ez volt a legnagyobb területủ, s területe egyre növekedett a népesség számának gyarapodásával. Falusias formájú, hézagos sorú, fóldszintes házak jellemezték. Az 
épületek hossztengelye az utcára meröleges volt. A teleklábas típusú telektömbökön belül nagy telkek, azokon pedig laza, fésủs falusias beépités, és az agrártevékenységhez szükséges nagy udvarok voltak megtalálhatók. Gyakorlatilag ez a falusias öv az óriásfalu megmaradt övezete volt.

Negyedik övként lehet megemlíteni a legkülsõ övet, az egykori szölôskerteket, az ún. "laza agglomerációt", amely többnyire nem érintkezett közvetlenül a régi zárt településsel, tỏle vagy egy lakatlan öv, vagy pedig a kialakulóban lévő, nagy helyigényü gyárakat, raktárakat és a pályaudvart magába foglaló iparforgalmi öv választotta el. Legfontosabb morfológiai jellemzöje, hogy nem alkotott egységes formacsoportot, rendkívüli sokszínüség jellemezte.

A XX. század második felében lényegesen megváltozott a morfológiai kép Hajdúböszörményben is. Az 1960-as évtizedben nagyszabású városépítési program indult el, s eredményeként egyre inkább kirajzolódott a település városias arculata. A cél a horizontális terjeszkedés meggátlása, a vertikális terjeszkedés támogatása volt. Ennek a célnak a több emeletes lakótömbök feleltek meg. Olyan helyeket kellett keresni a városban, ahol alacsony volt a beépítettség (a szanálási arány ne legyen nagyobb 15\%nál), de fejlett volt (vagy könnyen fejleszthetö) a közmühálózat.

Az '50-es évek végén épült az első többszintes lakás a Balthazár D. u. - Szoboszlói u. sarkản. 1965-ig a Kossuth L. utcán, 1965 és 1980 között a Szoboszlói - József A., Mester és Munkácsy M. utcákon épültek bérlakások, a '80-as évtizedben pedig a Györössy-kert területén (4. ábra), az Attila és Désány I. utcákon. A belsö mag és a kertség területén kispolgári, falusias, hóstáti városrészeket szanáltak, és helyükre korszerủ emeletes lakóházakat emeltek. A '90-es évek városképe így több lakóterületen alig emlékeztet a 2030 évvel korábbira. Az új morfológiai elem, a többszintes tömbös beépítés jobban megváltoztatta néhány évtized alatt a város arculatát, mint az előző évszázadok együttvéve. A lakótelepek építésével megnőtt a település vertikális szintje. Míg az 1960-as évtized elött még a városmagnak volt a legmagasabb vertikális szintje, addig ez napjainkban a belső lakóöv peremére került.

A többszintes lakótelepek építése - a települési környezet minőségére gyakorolt kedvezőtlen hatásai mellett - azonban több esetben helyrehozhatatlan károkat okozott a település szerkezetében és a városképben is. Az ilyen típusú építkezés megjelent a város belső magjában is (Kossuth $\mathrm{L}$. u., Weszprémi G. u., Petőfi S. u.), és a vertikális problémák mellett az üzletbérházak hiánya is sok, elsősorban funkcionális gondot okoz az adott területeken. (Financiális problémák miatt még a '80-as évtized végén épült Petöfi Weszprémi utcai többemeletes lakóházak földszintjén sem jöhetett létre üzletsor).

Ma - a nehéz gazdasági viszonyok közepette - a tömblakás építés szünetel, csak magánerős építkezések folynak a településen.

A lakótelepek építése idején kevesebb figyelem és pénz jutott a város egyéb belterületeire, többek között a belváros eredeti állapotban megmaradt részeire is, ahol az épültek nagy része ma rekonstrukcióra szorulna. Több településrészen a falusias viszonyok konzerválódtak (pl.: a Vénkert területén még 1959-ben sem volt emeletes ház). Kedvezó változást jelentett a családi társasházas épitkezés megerōsödése az egykori szólöskertek területén. Jobb telek-kihasználással, telkek megosztásával, több utca zegzugos futásának megszuntetésével, zsákutcák egy részének kinyitásával, új utcák nyitásával segítette a város vezetése a magánerős építkezést. A Középkert és a Vénkert területén is nyitottak új utcákat (pl.: Nefelejcs u., Elek J. u., Kovács A. u., Kövi M. u.). Közmüvesítettek, 
házhelyeket osztottak ki. Ennek eredményeként ma már a Vénkertben is találunk emeletes családi házakat, és a házaknak már többsége, $49 \%$-a tartozik a családi házas, villás típusba, míg a korábban domináns falusias típusú házak aránya 47\%-ra esẹtt vissza.

$\mathrm{Az}$ egykori ólaskert öv morfológiai sokszínüségével tủnik ki. Minden beépítési mód megtalálható területén, szórványként a társas- és ikerházas csoportos beépítés is (Gombos A. u.), amely a településrész modern városi arculatát erösíti.

Viszonylag új morfológiai elemet jelent az egykori szőlőskertek és a régi belsőségi perem közötti belsõ legelön kialakitott nagy helyigényủ gyárak, üzemek, raktárak és a pályaudvar alkotta iparforgalmi öv, amely nemcsak a városi arculat kialakulását segítette, hanem a városi munkaerö foglakożtatásában is óriási szerepet játszik, s így funkcionális értelemben második munkahelyövként értékelhetö.

Külön kell szólnunk a Bocskai tér morfológiai átalakulásáról. Két, építészetileg semleges épülettel lezárták a tér D-i, D-Ny-i részét. A két épületet (Mủvelődési Központ, volt MSZMP-székház) a tér szerves egészébe akarták beilleszteni, ami - szubjektív véleményem szerint - elsősorban az egykori pártháznál nem igazán volt sikeres. A település morfológiailag a múlt és a jelen keveréke, arculata igen változatos.

Legfontosabb övezetei:

Városközpont

A szanálások ellenére megtalálhatók az egykori kisvárosi formacsoport bizonyítékai: a zárt földszintes (kispolgári) és a félig zárt földszintes (hézagos kispolgári) sorházak, néhány helyen (pl.: Petőfi S. u.) a többszintes, zárt beépités is. Sok helyen a zártsorú egyemeletes házak földszintjének utcai részén üzleteket alakitottak ki. Ezek általában a nem mindennapi szúksségleteket ellátó szaküzletek. A második világháború után a városközpontban is elterjedt a családi házas építkezés; szórványként társasházi, s még napjainkban is falusias beépítések is jellemzik. A ' 60 -as évektô - új formai elemként többszintes, tömbös beépítés is történt a belsö lakóöv néhány nagyobb telektömbjének belsejében, ami a városközpont vertikális szintjét nagy mértékben megemelte. Sajnos ezeknek a lakótelepeknek a megépítése esztétikai értelemben sokat rontott a hangulatos, kisvárosias jellegủ városképen. Természetesen továbbra is itt találhatók meg a legjelentősebb közintézmények is. A városmag területe az elmúlt évtizedek morfológiai, funkcionális változásai eredményeképpen megnövekedett ÉK-i (Bethlen G. u. - üzletsor; Györössy-kerti lakótelep - amely új alközpontként funkcionál), K-i (Petöfi S. u. - piac; kisvárosi üzletnegyed kialakulása) és D-i (Szent I. tér - Kálvin tér) irányokban. A funkcionális értelemben vett városmag tehát itt már nem szabályos kör alakú, hanem csápszerủ nyúlványokkal oválisan megnyúlt.

Családi házas öv

Egykor az egységes falusias öv része volt - ma már morfológiailag nagyon vegyes összetételú. A falusias típusú épületek háttérbe szorultak, helyüket új típusú épületek vették át. A régebbi építésú családi házak sátortetősek; a legújabbak tetőtérbeépitésủek, sőt igen gyakran többszintes modern lakások. Az elmúlt három évtized során ezen az övön belül is épült néhány kisebb lakótelep (pl.: Attila u., Désány I: u.). A családi házas övön belül elsösorban a kedvező forgalmi fekvés határozza meg a településrészek fejlődését. Üzletekkel viszonylag jól ellátott; a kisebb üzletek, vegyeskereskedések egy-egy kisebb körzet ellátását biztositják.

Falusias öv

Egy része teljesen megszünt, egyre kisebb részre szorul vissza, hiszen ebbe az övbe is fokozatosan behatolt az urbanizáció. Ahol még fellelhető, ott az utcavonalhoz 
viszonyítva szabálytalan összevisszaságban találhatók meg az utcavonalát esetleg el sem éró, falusias jellegủ lakóházak. A teleklábas típus dominál, azaz a falusias házak egy- vagy kétablakos keskeny vége néz az utcára, a házak egyik hosszanti oldala a telekhatárhoz simul, a másik pedig az udvar felé nyílik. A mindennapi szükségleteket kielégító kisebb vegyeskereskedések, $\mathrm{ABC}$ üzletek még napjainkban is egészen szétszórtan találhatók a területén, ami a falusias öv viszonylagos ellátatlanságának bizonyítéka.

A szerkezeti és morfológiai képződményekre (alaprajz, beépítési mód) vonatkozó kutatásaimat a funkcionális övek lehatárolására szeretném kiterjeszteni. Az elózetes kutatásaim során hat ilyen övet tudtam elkülöníteni (Csapó 1990):

Városmag

Belsõ lakóöv

a./ városias része

b./ lakótelepek (belsö lakóöv tömbös része)

c./ falusias része

Külsőlakóöv a./ városias része

b./ falusias része

Ipari terület

Beépitetlen, egyéb terület

Külterületek - tanyák, amelyeknek már csak egy kis része lakott.

Ezek részletes feltárása folyamatban van, s reményeim szerint kutatásaim sikerrel hozzájárulhatnak Hajdúböszörmény tradicionális külső képének megóvásához; új, jellemzỏ jegyek bevonásával segíthetik a várostervezés, városfejlesztés munkáját.

\section{Irodalom}

Becsei J. (1976) Békéscsaba térbeli alkata. - In: Békéscsaba földrajza (Szerk.: Tóth J.). Békéscsaba, 415-488. o.

Bencsik J. (1975) A szőlöskertek építése Hajdúbőszörményben. - In: A Hajdúsági Múzeum Évkönyve II. Hajdúbőszörmény, 219-232. o.

Csapó T. (1990) Nagykanizsa funkcionális morfológiája. - Földrajzi Értesítō, XXXIV. 1-4. 151-173. 0.

Dám L. (1972) A hajdúböszőrményi szölök népi építkezése. - Közlemények a debreceni KLTE Néprajzi Intézetéböl, 25.

Den Hollander, A. N. J. (1980) Az Alföld települései és lakói. - Mg.-i Kiadó, Budapest. 112. o.

Györffy I. (1926) Hajdúböszörmény települése. Föld és Ember. Szeged, 36.14 o.

Hajdúbőszőrmény Általános Szabályozási és Övezeti Terve 1983. - Kelet-Magyarországi Tervezỏ Vállalat

Hajdúböszőrmény Egyszerúsített Általános Rendezési Terve 1959, - Városépítési Tervezó Vállalat.

Kathy I. (1979) Hajdúbőszörmény építészete. - In: Kathy I.-Sz. Kürti K.: Hajdúböszörmény ÉpitészeteKépzõmủvészete. Hajdúböszörmény, 11-58. o.

Mendöl T. (1936) Alföldi városaink morfológiája. - Közlemények a Debreceni Tisza István Tudományegyetem Földrajzi Intézetéból, Debrecen. 78. o.

Mendől T. (1963) Allalános településföldrajz. - Akadémiai Kiadó, Budapest. 567. o.

Novák L. (1975) Hajdúböszormény telek- és településrendszere. - In: A Hajdúsági Múzeum Évkönyve II. Hajdúböszörmény, 179-218. o.

Nyakas M. (1973) Városigazgatás a felszabadulás után. In: Hajdúböszörmény története (Szerk.: Szendrey I.). Hajdúböszörmény. 162-188. o.

Rácz I. (1973) A hajdúszabadság birtokában. - In: Hajdúböszörmény története (Szerk.: Szendrey 1.). Hajdúböszórmény. 62-120. 0 .

Szendrey I. (1973) A város népesedése. - In: Hajdúböszörmény története (Szerk.: Szendrey 1.). Hajdúböszórmény. 256-283. 0.

Újlaky Z,-né (1973) Ipar és kereskedelem Hajdúbőszörményben 1872-tôl napjainkig. - In: Hajdủböszörmény története (Szerk.: Szendrey I.) Hajdúbőszörmény. 492-523. o. 


\section{Abstract}

The present study examines those settlement morphological formations (base map, road network, arrangement of the sites, way of building up), in which the life of a town takes place. It attempts to fill a gap in the field, as the morphological aspects of urbanisation still have not been explored to the necessary depth. In my study I mainly analyse the development history of the base map and image of the settlement.

The choice of the settlement is explained by the settlement geographical features of Hajdúböszörmény. The town still bears its history in its appearance: Its most precious monument are the town itself and its morphology.

In the second half of the survey I processed the findings of a comparative morphological examination. The analysis of the former morphological picture and the comparisons are made possible by Tibor Mendöl's research in settlement geography, carried out 60 years ago. Primarily I examined the evolution of the shape, location, structure and size of the core of the town, by exploring morphological forms and ways of construction, putting their spatial arrangement onto a map. 